\title{
Economic Effects of Using Nepotism and Cronyism in the Employment Process in the Public Sector Institutions
}

\author{
Taha Barakat AL-shawawreh ${ }^{1, *}$ \\ ${ }^{1}$ Department of Administrative Science and Finance, Karak College University, Al-Balqa \\ Applied University, Karak, The Hashemite Kingdom of Jordan \\ *Correspondence: Department of Administrative Science and Finance, Karak College \\ University, Al-Balqa Applied University, Karak, The Hashemite Kingdom of Jordan. E-mail: \\ dr.tahashawawreh@yahoo.com
}

Received: August 20, 2015 Accepted: November 12, 2015 Published: March 30, 2016

doi:10.5296/rae.v8i1.9227ＵRL: http://dx.doi.org/10.5296/rae.v8i1.9227

\begin{abstract}
This study aims to discern the role of nepotism and cronyism in the weakening of economic performance of the government institutions through exposure to this practice in the three Arab Countries; Iraq, Saudi Arabia, and Jordan, The study relied on the analysis of what was stated in the related literature which illustrate the effect of using nepotism and Cronyism in the employment process in a governmental position, to result in a slowdown and stumbled in the delivery of government services to citizens. After analyzing how the practice of nepotism and cronyism in the three countries, the study found the following results:

- Nepotism and cronyism are practiced not only in developing countries, but also in advanced countries.

- Using nepotism and cronyism in employment process is unethical behavior.

- The use of nepotism and cronyism in the public sector is much more than private sector.

- Nepotism and cronyism can be considered as a part of the national culture in Arab countries.

- Nepotism and cronyism have negative economic repercussions, both at the level of the national economy, or the per capita income level. Because the salaries paid to staff recruited through them considered as a burden on the state treasury. Also, the large number of times to visit the citizen government department, to get the same service, lead to the loss of his income as a transition expenses.

- Nepotism and cronyism are from reasons of administrative corruption in the studied countries.
\end{abstract}

Keywords: Nepotism, Cronyism, Public Sector 


\section{Introduction}

In spite of the multiplicity of the Arab countries and the differences in political systems, but the prevailing culture in these countries seem Similar in many practices, especially since most of Arab States are governed by Tribal Systems. Accordingly, we find that nepotism and cronyism have become a dangerous phenomenon due to its involvement in multiple aspects such as the employment of people lack the scientific and practical efficiency in the positions may be sensitive and important, especially in the public sector institutions. Perhaps the reason for the spread of this phenomenon in the public sector in a larger degree of the private sector is that the private sector organizations have profitable goals that need effective employees who have the competence to achieve the final goal which is maximizing the owner's wealth. But the image is different in the public sector because often there are no measurable goals especially in the developing countries, where the citizen is forced to accept the public service regardless of superiority and quality.

The other side of nepotism and cronyism is the discrimination of treatment between the recipients of government services based on the common interests between the citizen and the employee, or the degree of family kinship, or belonging to the ruling party in the country. Where one may find that some citizens receive the service immediately while others have to wait in the waiting queue, or to wait for several days, or even several weeks. And this may affect or even cancel an investment decision which was taken by the citizen, thus harming the national economy.

This research comes to examine the role of nepotism and cronyism in weakening the economic performance in the institutions in the public sector in the Arab countries, with focus on Jordan, Iraq and Saudi Arabia.

\subsection{Problem Statement and Questions}

Because the intervention of nepotism and cronyism in the process of recruitment and employment of the staff in the public sector institutions, resulting in the presence of non-qualified staff, and do not have the ability and competence to do the job duties as signed to them, which leads to a general weakness in the level of performance, which reflected negatively on the satisfaction of citizens as consumers of government services. This problem was discussed according to the following questions:

1- How nepotism and cronyism affect the national economy and per capita income?

2- What is the citizen's perception when he is forced to wait longer time to receive the needed service, while the same service may provide to other citizen immediately?

3- What are the practical procedures that must be taken by governments to overcome this phenomenon?

\subsection{Significance of the Study}

The government as a big organization deals with all the layers of society whether they were business enterprises, or normal persons and employees, which means that the government 
provides multiple services to different people in terms of educational level, economic level, sex and ages. Therefore it becomes very necessary the selection of employees of government agencies in accurate ways far from the intervention of influential people, which may lead to employ unqualified persons. And here lies the significance of this study because this type of employees are lacking to the simplest rules of providing services.

\subsection{The Study Objectives}

This study aims to achieve the following objectives:

1- Identifying the role of government agencies in serving the society members.

2- To determine terms and characteristics that must be available in the person to fill governmental vacancies.

3- To identify the role of nepotism and cronyism in the employment process in government agencies.

4- To discern the impact of nepotism and cronyism on the economic performance of government agencies.

5- Make recommendations to reduce the intervention of nepotism and cronyism in government jobs.

\subsection{Methodology}

Since the main purpose of this research is to explore the effects of using nepotism and cronyism in the employment in government jobs, and the discrimination in treatment by the government employees with the citizens according to the social or political, or economical status of these people. Therefore the qualitative approach was used to conduct the research, Where the needed data was collected from the related literature that have debated this phenomenon in Iraq, Saudi Arabia, and Jordan to represent Arab countries.

\section{Literature Review and Theoretical Background}

\subsection{Literature Review}

There are a lot of studies in the literature that have addressed the effects of employing some persons according to family relations, or friendship or political affiliation. The researcher has selected the following studies:

1- Study by Lumijarvi and Ursin (2011) under the title: "can a high performance public organization be highly ethical as well?"

The study aimed to enhance the public understanding about the interaction and the mutual relationship between integrity and performance. The study was conducted on the Finnish Police units by distributing a questionnaire to a sample consists of 177 respondents working in the police units in the western district of Finland. The results showed that unethical behavior such as flattery by employees and nepotism by managers are from the factors 
leading to weak performance. While the ethical behavior has positive effects on both performance and effective staff. According to these results the researchers recommended managers in the public sector institutions to resist nepotism and cronyism.

2- Study byzudenkova (2011) under the title: "Cronyism in Business. Public sector and politics".

This study aimed to illustrate the incentives for cronyism in business enterprises, and the public sector, and politic organizations, within an agency problem model with moral hazard. The analysis was based on essential assumption about the top management's preferences and hiring procedures within the firm, a bureaucratic organization or a cabinet of ministers. The result showed a high consistency with the pre-assumption, where, the general director of a business enterprise cares for economic advantage for him through his monetary payoffs. Therefore he gives attention to hire qualified people in order to achieve the goals which leads to additional rewards to him and to the staff. While in the public sector organizations, the only concern of the director or the president or the minister is to be re-appointed or reelection. And this forced him to submit to the pressures of influential people to hire people through nepotism, then the final result of this action retlects on the performance level.

3- Study by Altindag (2014) under the title: "Evaluation of Nepotism As Accelerating Effect on Employee Performance: An Empirical Study in Turkey".

This study aimed to explore the effects of nepotism on the employee performance, and to find out the strategic role that can be played by nepotism in such relation. The study was conducted on telecommunication and logistic sectors in Istanbul Anatolian Side. The results of data analysis showed that nepotism does not have a direct impact on employee performance. This result came to oppose what the researcher believes that nepotism causes a certain amounts of dis advantages, and it is possible at the same time to create more loyal employees to the firm.

4- Study by Bute (2011) under the title: "The Effects of Nepotism and favoritism on Employee Behaviors and Human Resources Practices: A Research on Turkish public Banks."

This study aimed to analyze the effects of nepotism on employee's behaviors and HRM Practices in Turkish public banks. The study was conducted on the public banks operating in Ankara. Data was collected through distributing 300 questionnaire, 243 of them were valid to analysis. The results showed that nepotism had significant negative effects on job satisfaction, organizational Commitment and HRM Practices, and individual Performance.

5- Study by Karakose (2014) under the title: "The Effects of Nepotism, Cronyism and Political Favoritism on the Doctors Working in public Hospitals".

This Study aimed to investigate the opinions of doctors working in Turkism hospitals about the implementations of nepotism and cronyism, and Political favoritism and identifying the effects of such implementations on doctors. The study was conducted on a Sample of 26 Specialist doctors working in Public hospitals in the city of Kutahya. Data was collected by 
using Semi structured interviews with the participants. The results showed that favoritism from the point of view of the participants pertains to unethical behaviors. And unfairness in appointing managers was considered as one of the main favoritism implementation in hospitals. Therefore, such implementations may damage the sense of fairness of workers; destroy team spirit, lead to low performance and a result to individual and organizational failure.

6- Study by lowew and Speer (2008), under the title: "How Favoritism affects the business Climatic Empirical Evidence from Jordan".

This study aimed to shed light on the effects of favoritism on the business climate in Jordan. The study was conducted through a research team from the German Development Institute whom carried out empirical research in Jordan for 11 weeks in early 2006. The research reached the following results:

- Favoritism or "using wasta" as called in Jordan, contributes significantly to a number of problems. Using wasta most likely helps investors to speed up procedures to get exclusive access to services and information.

- People with good wasta may influence legislations to their advantage.

- Entrepreneurs prefer to invest their time and money in social relations instead of productive capital, because their success depends on their wasta rather than the quality of their products.

7- Study by Singh and Twalo (2014) under the title: "Impact of Human Factors on the Labour Process: A Case Study".

This study aimed to reveal the factors behind the poor administration, weak management of resources, inadequate job performance, and negative functional behavior, in Buffalo City Metropolitan Municipality (BCMM) in South Africa. The study was conducted according to case study approach; data was collected through conducting semi - structured interviews with sampled workers from various departments and in different ranks. The results showed that nepotism is a real threat for the labor market in the country because the appointment of employees by nepotism creates serious effects on job performance, because workers, who got their jobs or promotion through it, also got protected by their sponsors.

8- Study by Donaldson (2001) under the title: "The Ethical Wealth of Nations".

This study aimed to examine the Potential economic effects of the ethical wealth for nations. The study was based on the main question, about the ethical factors that may lead to a high level of national economic performance. The results showed that economic success can achieved by the existence of good government, and respect for intellectual property, and avoiding nepotism "crony capitalism". The current researcher sees also, nepotism may work to transfer the intellectual property from self-made citizen to other who is supported by influential person. 


\subsection{Theoretical Background}

The nepotism and cronyism are terms almost have the same meaning. But some differences may be observed according to the objectives of the discussion, where some authors have defined cronyism as partiality which due to a long friendship between two or more persons (Zudenkovea, 2011). Mostly cronyism is used in employment process, where the manager in the organization may hires friend or relative in a job regardless of his qualifications and skills. For example about cronyism intervention in appointing employees in public jobs, the literature pointed out that the appointment of Robert S. McNamara as secretary of defense by president John Kennedy was due to the long friendship between them (Zudenkova, 2011). From here we can say that nepotism and cronyism may be practiced even in advanced countries. Other researchers have defined the two terms nepotism and cronyism through the differences among them. In this regard (Ozsemerci, 2003 and Tarhan et al, 2006). Pointed out that, in nepotism the favored person is relative, while in cronyism the favored person is a friend. From the perspective of the current researcher, this definition is incomplete, and that because the relative or the friend may be eligible qualified well and has a strong skill entice organizations to recruit him to work, regardless of his relationship with the manager, and thus the role of nepotism and cronyism have negated. While (Boadi, 2000, 197) sees nepotism as a kind of conflict of interests, and it is a behavior practiced to provide income, job or other economic advantage in an unethical way to a relative or somebody from family, or hiring someone in a job does not have a right to occupancy. While, the most accurate definition from the perspective of the current researcher is that nepotism and cronyism are two of unethical practices, especially in the business world, where, hiring relatives or friends in jobs that do not deserve it because of the lack of the necessary qualifications and skills, which means depriving qualified person, which will reflect negatively on the quality of performance and reduce the productivity (Nadler and Schulman, 2005).

In order to achieve the objectives of this research, it becomes necessary to identify the role of the public employee in providing government services to the community members. The government is a big organization deals with the largest number of customers (citizens) from different levels, and the government institutions work to exchange information and services with multiple categories such as business enterprises, citizens, employees and other states (Tanuwidjaja, 2006). Therefore, the government employee must feel that he obtains his salary in exchange providing and submitting governmental services to the beneficiaries. In addition to the sufficient Knowledge about the importance of providing the service in the appropriate time without any delay that may lead to lose the opportunities that the citizen seeks to get them. Such as, investment or travel, or attending conference, or enrollment to the university. This simply tells us that government institutions have to be eager to recruit qualified applicants who have the sufficient skills to deal with all levels of the community members in accurate ways, and stay away from the recruitment of staff by the intervention of nepotism and cronyism, because it will reflects on the performance of the whole government from the perspective of the beneficiary.

In order to reveal the impact of employing candidates through nepotism and cronyism, the government institution performance in the Arab World; Iraq, and Saudi Arabia, and Jordan, 
had been selected by the researcher to complete the debate about this unethical practice.

The related literature indicates that the government institutions in Iraq suffer from many Kinds of corruption; administrative corruption, financial corruption, even political and juridical corruption (Al-Lami, 2007). Perhaps one of the more manifestations of corruption in the country is, rampant nepotism and cronyism in different aspects. In this regard, the literature (www.nazaha.com) points out that nepotism is the implementation of the work for the benefit of an individual person or party he belongs, such as family or party or region, without that person is worthy of this business. Therefore, the efforts of public employees will focus only to serve that person regardless the public benefit, which will distort the image of performance. While cronyism means the intervene on behalf of an individual or group without the obligation of working conditions and the necessary competence, such as the appointment of a person in a particular position for reasons of kinship or party affiliation, in spite of the lack of efficiency and lack of eligibility in occupancy this job position, causing delay in the economic interests of the state and the citizen.

For the kingdom of Saudi Arabia the situation is different, because the labor market relies heavily on foreign workers, where the ministry of labor pointed out that the deportation of foreign workers that are contrary to the low of work and residence, which amounted to more than 170,000 workers during the past forty days was the reason for empting Saudi labor market (Faqih, 2014). This and other factors such as Saudization that requires the replacement of foreign workers with national workers, led to increase the intervention of nepotism and cronyism in the employment process especially in the public sector. (Askar et al, 2011) pointed out that a large segment of young Saudis prefer to work in the public sector because of the low requirements of daily work. And this from the point of view of the current researcher forms on evidence an the weak performance in Saudi Public Sector institutions. In this regard (Fawzi, 2014) pointed out that employment in Saudi Public Sector institutions can be either through the Civil Service Commission or a more direct way, which is under a lot of pressure from nepotism and cronyism. Where the employee who was appointed under the pressure of nepotism and cronyism will be enjoyed to spend few hours in the work place and get a high salary without doing any effort to satisfy the citizens. Moreover, he may affect negatively the performance of co-workers, which may reduce their productivity.

In Jordan, it seems that nepotism and cronyism have become an integral part of the culture of Jordanian society. Abu Dahers (2007) has defined nepotism as the acceptance of public employee to please, or recommendation, or pressure from others, be based on the violation of the law to emplement the request of the need, without any right, and therefore it is considered a breach of the functional lead to looting right, or the realization void, and ultimately a waste of public money, which harms heavily in the national economy.

Given the seriousness of the practice of nepotism and cronyism, the Jordanian legislator issued the anti-corruption low No.62 for the year 2006, which explicitly criminalize nepotism, as one of the crimes of corruption (www.Jacc.gov.jo). 


\section{Results and Recommendations}

\subsection{Results}

The main findings of this study can be summarized as follows:

- Nepotism and cronyism are practiced not only in developing countries, but also in advanced countries.

- Using nepotism and cronyism in employment process is unethical behavior.

- The use of nepotism and cronyism in the public sector is much more than private sector.

- Nepotism and cronyism can be considered as a part of the national culture in Arab countries.

- Nepotism and cronyism have negative economic repercussions, both at the level of the national economy, or the per capita income level. Because the salaries paid to staff recruited through them considered as a burden on the state treasury. Also, the large number of times to visit the citizen government department, to get the same service, lead to the loss of his income as a transition expenses.

- Nepotism and cronyism are from reasons of administrative corruption in the studied countries.

\subsection{Recommendations}

The researcher presents some recommendations especially to the public sector in the Arab Countries:

- Arab countries must be adhered to apply the provisions of monotheistic religions, which call for equality between people.

- The ministries of information in the Arab countries can hold educational seminars, broadcast on television, call to get rid of these unethical practices and inconsistent with the heavenly religions.

- Arab countries must issue laws that criminalize nepotism and cronyism, because staff recruited through nepotism and cronyism causing lower productivity.

\section{References}

Al-Lami, Mazen. (2007). Corruption Between Transparency and Tyranny. Dania Press, first Edition, 2007, Baghdad. Retrieved from www.nazaha.iq/body.asp?field=news_arabic\&id=473

Altindage, Erkut. (2014). Evaluation of Nepotism As Accelerating Effect on employee Performance: An Empirical Study in Turkey. European Journal of Business and Social Sciences, 3(7), 97-104. 
Askar, Abdullah. (2011). Employment: Is It Still an Advantage to the Public Sector? Yamamah Press Foundation. Retrieved from www.jacc.gov.jo

Boadi, E. Gyimah. (2000). Conflict of Interest, Nepotism and Cronyism. Confronting Corruption: The Elements of A National Integrity System, 195-204.

Bute, Mustafa. (2011). The Effects of Nepotism and Favoritism on Employee Behaviors and Human Resources Practices: A Research on Turkish Public Banks. ToDaies Review of Public Administration, 5(1), 185-208.

Donaldson, Thomas. (2001). The Ethical Wealth Of Nations. Journal of Business Ethics, 31(1), 25-36.

Faqih, Adel, Minister of Labor in Saudi Arabia. (2014). Assawsana Newspaper. Newsid, 162240.

Fawzi, Naif. (2014). How Does the Saudi Public Sector Exercise the Practices of Human Resource Management? International Journal of Human Resource Studies, 5(1), 167-173.

Karakose, Turget. (2014). The Effects of Nepotism, Cronyism and Political Favoritism on Doctors Working in public Hospitals. Ethno Med, 8(3), 245-250.

Lowec, Markus, Blume, Jonas \& Speer, Johanna. (2008). How Favoritism affects the Business climate: Empirical Evidence from Jordan. The Middle East Journal, 62(2), 259-276.

Lumijarvi, Ismo \& Ursin, Klaus. (2011). Can a High Performance Public Organization be highly Ethical as Well? University of Tampere, Finland.

Nadler, Judy \& Schulman, Miriam. (2006). Favoritism, Cronyism, and Nepotism. Santa Clara University.

Ozsemerci, K. (2003). Corruption in Turkey Public Administration, causes, loss and Solutions. Ankara Alpine Publications.

Singh, Parakash \& Twalo, Thembinkosi. (2014). Impact of Human Factors on the Labour Process: A Case Study. International business and Economic Research Journal, 13(2), 305-318.

Tanuwidjaja, E. (2006). Economic Analysis on E-Government (A Case Study of E-Government in Singapore). National University of Singapore.

Tarhan, RB. (2006). Combating Corruption, Parliamentary Report as a phenomenon Corruption: Causes, Impacts, Solutions. Ankara: TEPAV: Anti-corruption Books-1. Masta Press.

Zundenkova, Galina. (2011). Cronyism in Business, Public Sector and Politics. MPRA Paper No.30231, Posted 15. April 2011 14:51 UTC. 


\section{Copyright Disclaimer}

Copyright for this article is retained by the author(s), with first publication rights granted to the journal.

This is an open-access article distributed under the terms and conditions of the Creative Commons Attribution license (http://creativecommons.org/licenses/by/3.0/). 